\title{
REHABILITASI MEDIK PADA HEMOFILIA
}

\author{
Vincentius Yoshua \\ Engeline Angliadi
}

\author{
Bagian/SMF Ilmu Kedokteran Fisik dan Rehabilitasi \\ Fakultas Kedokteran Universitas Sam Ratulangi Manado \\ Email: vincentius.yoshua@gmail.com
}

\begin{abstract}
Haemophilia is an inherited disorder of blood coagulation with sex-linked recessive and autosomal recessive characteristics. It may manifest itself by prolonged bleeding (internal or external) and clotting formation disturbances that need a multidiciplinary management. This disease is initiated at the neonatal stage. The diagnosis is based on anamnesis, physical examination, and other supporting examinations, such as homeostasis functions. The most common complications are found in the musculoskeletal system and auto-antibody (inhibitor) reaction against clotting factors VIII or IX. A pharmacological approach to haemophilia depends on the clinical signs, but medical rehabilitation's approach is focused on all life aspects of the patient. This approach has to be done as early as possible to avoid threatening disabilities and handicaps affecting the musculoskeletal system. Team work is needed to achieve a minimalization of musculoskeletal complications and to realize a more promising better prognosis.
\end{abstract}

Keywords: haemophilia, complications, bleeding, musculoskeletal, rehabilitation.

\begin{abstract}
Abstrak: Hemofilia adalah kelainan pembekuan darah dengan karakteristik sex-linked resesif dan autosomal resesif, disertai masalah perdarahan dan kelainan pembekuan yang memerlukan penanganan multidisipliner. Gejala yang paling sering terjadi ialah perdarahan, baik di dalam tubuh (internal bleeding) maupun di luar tubuh (external bleeding). Perjalanan penyakitnya sendiri sudah dimulai dari masa neonatal. Diagnosis dapat ditegakkan dari anamnesis, pemeriksaan fisik dan pemeriksaan penunjang berupa pemeriksaan fungsi homeostasis. Komplikasi yang paling sering ditemukan ialah komplikasi muskuloskeletal dan reaksi auto-antibodi (inhibitor) terhadap faktor pembekuan darah sendiri baik terhadap faktor VIII atau faktor IX. Pendekatan farmakologik pada hemofilia tergantung dari gejala klinis yang muncul namun pendekatan rehabilitasi medik pada hemofilia tidak tergantung gejala klinis yang muncul karena pendekatan ini lebih difokuskan ke seluruh aspek kehidupan pasien hemofilia. Pendekatan ini sudah harus dilakukan sejak dini mengingat komplikasi yang mungkin ditimbulkan, yang dapat menyebabkan disabilitas dan handicap, tersering akibat komplikasi muskuloskeletal. Dengan penanganan rehabilitasi medik yang berbasis pendekatan tim, diharapkan komplikasi muskuloskeletal dapat diminimalisasikan dan prognosis pasien hemofilia dapat lebih baik.
\end{abstract}

Kata kunci: hemofilia, komplikasi, perdarahan, muskuloskeletal, rehabilitasi.

Hemofilia adalah kelompok kelainan pembekuan darah dengan karakteristik sexlinked resesif dan autosomal resesif. Gejala yang paling sering terjadi ialah perdarahan, baik di dalam tubuh (internal bleeding) maupun di luar tubuh (external bleeding).
Masalah perdarahan dan kelainan pembekuan disini harus ditangani secara pendekatan tim. ${ }^{1,2}$

Prevalensi hemofilia di Indonesia untuk pada tahun 2006 ialah 4,1 per 1 juta kasus. Kasus hemofilia A lebih sering 
ditemukan dibandingkan dengan hemofilia B yaitu tercatat sebanyak 1 per 10 ribu kasus sedangkan kasus hemofilia B 1 per 20-30 ribu kasus. Untuk kasus hemofilia C di Indonesia belum terdapat data resmi karena kasus ini jarang ditemukan, diperkirakan 1 per 100 ribu kasus hemofilia., ${ }^{4,5}$

Rehabilitasi medik merupakan faktor penting dalam penanganan hemofilia terutama dalam penanganan akibat dari komplikasi muskuloskeletal. Pendekatan tim dalam hal ini mutlak harus dipenuhi sehingga dapat membantu pasien dan keluarga sampai pada masalah psikososial dan kehidupan sehari-hari.,

\section{DEFINISI}

Hemofilia adalah kelompok kelainan pembekuan darah dengan karakteristik sexlinked resesif dan autosomal resesif, dimana perdarahan dapat terjadi tanpa penyebab trauma yang jelas atau berupa perdarahan spontan. Hemofilia dibagi atas tiga jenis yaitu hemofilia $A, B$, dan C. Hemofilia A dan B diturunkan secara seksual, sedangkan hemofilia C secara autosomal. Pada kasus hemofilia A terdapat defisiensi faktor VIII; kasus hemofilia B dengan defisiensi faktor IX; dan hemofilia $\mathrm{C}$ dengan defisiensi faktor XI. ${ }^{1,2}$

\section{PROSES PEMBEKUAN DARAH}

Proses pembekuan darah adalah proses dimana darah membentuk suatu bekuan darah (clot). Hal ini sangat penting dalam menjaga homeostasis bila terjadi perdarahan akibat trauma terhadap pembuluh darah maupun jaringan di sekitar pembuluh darah. Proses pembekuan darah terdiri dari dua jalur pembekuan yaitu jalur intrinsik dan ekstrinsik. Jalur intrinsik merupakan jalur pembekuan darah ketika terjadi trauma/kerusakan pada pembuluh darah itu sendiri sedangkan jalur ekstrinsik terjadi pada trauma/kerusakan jaringan di sekitar pembuluh darah. Kedua jalur ini bekerja secara bersamaan dalam menjaga homeostasis. $^{6}$

\section{GEJALA KLINIS HEMOFILIA}

Gejala yang paling sering terjadi pada hemofilia ialah perdarahan, baik yang terjadi di dalam tubuh (internal bleeding) maupun yang terjadi di luar tubuh (external bleeding). Internal bleeding yang terjadi dapat berupa: hyphema, hematemesis, hematoma, perdarahan intrakranial, hematuria, melena, dan hemartrosis. Terdapatnya external bleeding dapat bermanifestasi sebagai perdarahan masif dari mulut ketika ada gigi yang tanggal atau pada ekstraksi gigi; perdarahan masif ketika terjadi luka kecil; dan perdarahan dari hidung tanpa sebab yang jelas. ${ }^{8,9}$

\section{PERJALANAN PENYAKIT}

\section{Periode neonatal}

Periode neonatal ialah rentang waktu sejak kelahiran sampai 28 hari post natal. Perdarahan intrakranial (intracranial hemorrhage, ICH) biasanya merupakan tanda pertama yang dapat ditemukan pada periode ini. Riwayat hemofilia dalam keluarga merupakan hal penting dalam menentukan teknik persalinan untuk mengurangi risiko trauma persalinan. ${ }^{10,11}$

\section{Periode infant, toddler dan child}

Periode infant dimulai setelah neonatal sampai usia 1 tahun, kemudian beralih ke periode toddler sampai usia 2 tahun, selanjutnya periode child sampai usia 10 tahun. $^{12}$ Pada periode infant dan toddler, risiko terjadinya perdarahan menjadi lebih tinggi seiring dengan perkembangan dan pertumbuhan bayi yaitu mulai belajar untuk duduk, merangkak, berdiri, berjalan, dan berlari. Hematom dan hemartrosis mulai ditemukan pada periode ini. Selain itu, pemberian imunisasi juga memerlukan perhatian khusus karena imunisasi biasanya diberikan secara intramuskular. $^{13}$

\section{Periode adolescent dan adult}

Periode adolescent ialah rentang waktu 
usia 10-19 tahun, dan selanjutnya adult sampai usia 64 tahun. $^{12}$ Pada periode adolescent, amigdala yang bertanggung jawab terhadap perilaku instingtual berkembang pesat sedangkan lobus frontal yang berfungsi dalam reasoning, yaitu perilaku untuk berpikir dahulu sebelum bertindak belum berkembang sempurna. ${ }^{14}$ Olah raga dan permainan yang memacu adrenalin biasanya menjadi bagian dari kehidupan anak yang dapat meningkatkan risiko terjadinya perdarahan baik internal maupun eksternal. ${ }^{15}$

Pada periode adult, fungsi lobus frontalis dalam hal reasoning sudah berkembang baik. Pasien hemofilia sudah cukup dewasa untuk menyesuaikan diri sehingga umumnya risiko terjadinya perdarahan atau komplikasi lainnya dapat dihindari. $^{15}$

\section{DIAGNOSIS DAN DIAGNOSIS BANDING HEMOFILIA}

\section{Diagnosis hemofilia}

Pemeriksaan komprehensif pada pasien dengan suspek hemofilia sudah harus dimulai saat ditemukan riwayat: penyakit hemofilia dalam keluarga; mudah memar sejak periode neonatal; perdarahan spontan baik internal atau eksternal; dan perdarahan masif ketika terjadi luka kecil. Kecurigaan ini kemudian ditindaklanjutkan dengan skrining laboratorium untuk mengetahui fungsi homeostasis serta ada tidaknya kelainan perdarahan. ${ }^{16}$ Skrining utama untuk menentukan fungsi homeostasis ialah platelet count (normal 150.000$450.000 / \mathrm{mm}^{3}$ ) dan bleeding time. Pada pemeriksaan platelet count, pengambilan darah dilakukan melalui pungsi vena; dan perlu diperhatikan apakah pasien sedang mengonsumsi obat-obatan seperti kloramfenikol, oral anti-tuberculosis (OAT), colchicine, atau sulfonamid. Pemeriksaan bleeding time menggunakan metode Ivy dengan nilai normal 1-6 menit, dan dikatakan memanjang bila $>15$ menit. ${ }^{17}$

Selain platelet count dan bleeding time, hal-hal lain yang harus diperiksa ialah prothrombin time (PT), activated partial thromboplastin time (aPTT), thrombin time (TT), serta specific coagulation factor assay untuk FVIII dan IX. Pada keempat pemeriksaan ini, pengambilan darah dilakukan melalui pungsi vena. Pemeriksaan PT untuk menilai jalur pembekuan darah ekstrinsik, yaitu keterlibatan faktor I, II, III, IV, V, VII, dan X dalam proses pembekuan darah, dengan nilai normal 11-13 detik. Pemeriksaan aPTT untuk menilai jalur pembekuan darah intrinsik yaitu keterlibatan faktor VIII, IX, XI, dan XII, dengan nilai normal 15-35 detik. Pemeriksaan TT untuk menilai kemampuan membentuk bekuan darah darah dari fibrinogen yaitu keterlibatan faktor XIII dalam proses pembekuan darah. Pemeriksaan specific coagulation factor assay untuk FVIII dan IX dilakukan untuk menilai aktivitas faktor VIII dan IX, dengan nilai normal dari faktor VIII dan IX assay 60-100\%. ${ }^{17}$

Berdasarkan hasil pemeriksaan di atas, hemofilia dikategorikan: ringan bila aktivitas faktor pembekuan 5-35\% dari normal; sedang, bila aktivitas faktor pembekuan 15\% dari normal; dan berat, bila aktivitas faktor pembekuan $<1 \%$ dari normal ${ }^{18}$

\section{Diagnosis banding hemofilia}

Beberapa jenis kelainan darah yang dapat menjadi diagnosis banding dari hemofilia ialah: trombositopenia; defisiensi faktor VIII, IX, dan XI; defisiensi faktor II, $\mathrm{V}, \mathrm{X}$, dan vitamin $\mathrm{K}$; defisiensi faktor VII dan penyakit hati; Von Willebrand's disease; disseminated intravascular coagulation (DIC); dan defisiensi faktor XIII. Pemeriksaan penunjang yang perlu dilakukan untuk menegakkan diagnosis atau menyingkirkan diagnosis banding dapat dilihat pada Tabel 1.

\section{KOMPLIKASI MUSKULOSKELETAL}

Komplikasi yang paling sering terjadi pada kasus hemofilia ialah komplikasi muskuloskeletal dan reaksi auto-antibodi (inhibitor) terhadap faktor pembekuan darah itu sendiri, baik terhadap faktor VIII 
Tabel 1. Diagnosis banding hemofilia ${ }^{17}$

\begin{tabular}{lcccc}
\hline \multicolumn{1}{c}{ Kelainan perdarahan } & \multicolumn{3}{c}{ Pemeriksaan } & \\
& PC & PT & aPTT & BT \\
\hline Trombositopenia & $\downarrow$ & $\mathrm{N}$ & $\mathrm{N}$ & $\uparrow$ \\
Defisiensi faktor VIII,IX,XI & $\mathrm{N}$ & $\mathrm{N}$ & $\uparrow$ & $\mathrm{N}$ \\
Defisiensi faktor II,V,X dan Vit K & $\mathrm{N}$ & $\uparrow$ & $\uparrow$ & $\mathrm{N}$ \\
Defisiensi faktor VII penyakit hati & $\mathrm{N}$ & $\uparrow$ & $\mathrm{N}$ & $\mathrm{N}$ \\
Von Willebrand's disease & $\mathrm{N} / \downarrow$ & $\mathrm{N}$ & $\mathrm{N} / \uparrow$ & $\uparrow$ \\
DIC & $\downarrow$ & $\uparrow$ & $\uparrow$ & $\uparrow$ \\
Defisiensi faktor XIII & $\mathrm{N}$ & $\mathrm{N}$ & $\mathrm{N}$ & $\mathrm{N}$ \\
\hline
\end{tabular}

atau faktor IX. Komplikasi muskuloskeletal yang dapat terjadi ialah artritis hemofilik dan perdarahan otot (Tabel 2). ${ }^{19}$

Berdasarkan patofisiologinya, artritis hemofilik dapat dibagi menjadi tiga stadium, yaitu hemartrosis akut, sinovitis kronis, dan artritis degeneratif (Gambar 1). Pada perdarahan sendi, posisi nyaman bagi pasien ialah cenderung posisi fleksi. Kondisi ini akan memengaruhi otot-otot stabilisator di daerah tersebut. Kelemahan otot stabilisator akan memicu kerja otototot mobilisator di dekatnya untuk menggantikan fungsinya sebagai stabilisator, sehingga otot-otot mobilisator akan cenderung overcontracted yang berakibat mudah terjadi fatique (otot mobilisator terdiri dari serat otot tipe IIb). Kondisi ini rawan bagi otot untuk terjadinya perdarahan otot. $^{20}$

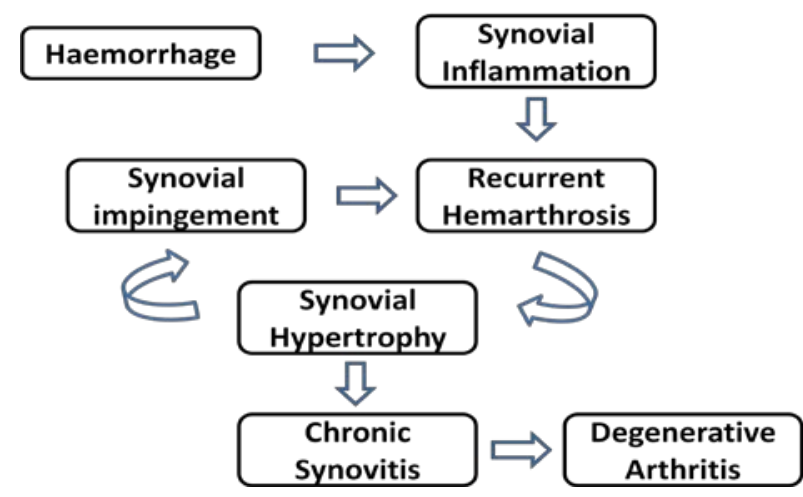

Gambar 1. Artritis hemofilik. ${ }^{19}$

Tabel 2. Protokol penanganan kasus kelainan pembekuan darah berdasarkan kadar plasma spesifik ${ }^{19}$

\begin{tabular}{|c|c|c|}
\hline Gejala & Penanganan & Rekomendasi kadar plasma \\
\hline $\begin{array}{l}\text { Mild bleeding episodes } \\
\text { - Mimisan } \\
\text { - Memar } \\
\text { - Gusi berdarah }\end{array}$ & $\begin{array}{l}\text { Hanya observasi, tidak } \\
\text { dilakukan penanganan } \\
\text { khusus }\end{array}$ & Tidak ada \\
\hline $\begin{array}{l}\text { Moderate bleeding } \\
\text { episodes } \\
\text { - Hemartrosis } \\
\text { - Perdarahan otot } \\
\text { - Mimisan berulang } \\
\text { - Perdarahan mulut }\end{array}$ & $\begin{array}{l}\text { - Penilaian perdarahan } \\
\text { - Pemberian faktor pembekuan } \\
\text { - Pengulangan faktor dalam } 24 \\
\text { jam apabila tidak membaik }\end{array}$ & $\begin{array}{l}40-50 \% \text { kadar plasma } \\
\text { faktor pembekuan darah } \\
\text { (VIII / IX) } \\
\text { (20-25 unit per kgBB) }\end{array}$ \\
\hline $\begin{array}{l}\text { Severe bleeding episodes } \\
\text { - Susp ICH } \\
\text { - Perdarahan mata } \\
\text { - Perdarahan yang } \\
\text { mengancam nyawa } \\
\text { (A,B,C) }\end{array}$ & $\begin{array}{l}\text { - Emergency room } \\
\text { - CT-scan / MRI kepala } \\
\text { - Pemberian faktor pembekuan } \\
\text { - Team approach }\end{array}$ & $\begin{array}{l}\text { 80-100\% kadar plasma } \\
\text { faktor pembekuan darah } \\
\text { (VIII / IX) } \\
\text { (40-50 unit per kgBB) }\end{array}$ \\
\hline
\end{tabular}




\section{PENANGANAN HEMOFILIA}

Protokol penanganan kasus kelainan pembekuan darah yang dianjurkan berdasarkan kadar plasma spesifik, yakni kadar faktor pembekuan VIII/IX dalam darah. ${ }^{19}$

Pada kasus hemartrosis, bila tidak didapatkan respons dengan pemberian terapi hematologi, perlu dipikirkan tindakan joint aspiration (arthrocentesis). Tindakan ini harus dilakukan 3-4 hari setelah onset hemartrosis untuk mengistirahatkan sendi yang terkena, sehingga pada saat joint aspiration dilakukan, inflamasi yang terjadi tidak terlalu hebat (joint aspiration sendiri sudah bersifat invasif). Joint aspiration ditujukan untuk membantu mengurangi nyeri dan meningkatkan lingkup gerak sendi. Kontraindikasi joint aspiration ialah adanya proses infeksi baik sistemik maupun lokal yang sedang berlangsung. Pemilihan ukuran jarum sekitar 25-30G untuk mengurangi nyeri saat penusukan dan inflamasi setelah joint aspiration selesai dilakukan. ${ }^{20}$

\section{REHABILITASI MEDIK}

Penanganan rehabilitasi medik ini dimulai dari pemeriksaan fisik. Pemeriksaan fisik harus dilakukan dengan hati-hati agar tidak memicu terjadinya perdarahan; dalam hal ini, komunikasi antara terapis dan pasien menjadi kunci utama. Komponen pemeriksaan fisik terdiri dari observasi, lingkup gerak sendi dan fungsi otot, serta pemeriksaan status neurologik. ${ }^{21}$

Observasi meliputi respons pasien terhadap terapi faktor pembekuan darah VIII atau IX; respons pasien terhadap aktivitas fungsional seperti duduk, berdiri, atau berjalan; dan gangguan postur atau pola berjalan, dan ada tidaknya perbedaan panjang kedua tungkai. Mengenai lingkup gerak sendi dan fungsi otot, perlu dilakukan pencatatan keadaan sendi dan otot sebelum dan selama follow up (edema, nyeri, lingkup gerak sendi, deformitas, dan lingkar sendi atau otot yang terkena). Pemeriksaan status neurologik penting dilakukan karena komplikasi muskulo- skeletal dapat menyebabkan gangguan neurologik misalnya neuropati perifer pada hemofilia berat.

Pemeriksaan penunjang dilakukan untuk membantu menegakkan diagnosis dan penanganan komplikasi muskuloskeletal. Untuk hemartrosis, klasifikasi radiologik yang digunakan berdasarkan ArnoldHilgartner. Pada komplikasi perdarahan otot, penggunaan ultrasound dapat memberikan informasi tentang distribusi perdarahan otot yang terjadi. Untuk kepentingan ini, frekuensi ultrasound yang digunakan 712 Mhz dengan transduser jenis linear array transducer. ${ }^{21}$ Panduan penatalaksanaan rehabilitasi medik untuk hemofilia yang disertai komplikasi dapat dilihat pada Tabel 3. ${ }^{21}$

\section{PROGNOSIS}

Prognosis pasien hemofilia sebenarnya baik bila semua pihak yang terlibat senantiasa bekerja sama dalam menghadapi penyakit ini. Disabilitas berat dan kematian akibat hemofilia serta komplikasinya hanya terjadi sekitar 5-7\% pada hemofilia berat. Penentuan prognosis pada hemofilia tidak sepenuhnya tergantung pada komplikasi yang terjadi, melainkan harus dilihat secara keseluruhan termasuk masalah psikososial yang terkait dan tingkat kepercayaan diri pasien. ${ }^{21}$

\section{SIMPULAN}

Hemofilia adalah kelompok kelainan pembekuan darah dengan karakteristik sexlinked resesif dan autosomal resesif. Kelainan pembekuan darah disebabkan oleh kurangnya faktor pembekuan darah VIII atau IX. Komplikasi hemofilia terutama mengenai sistem muskuloskeletal yaitu adanya hemartrosis atau perdarahan otot. Perjalanan penyakit hemofilia yang kronis dapat menyebabkan disabilitas dan handicap; oleh karena itu dibutuhkan suatu pendekatan tim. Dengan penanganan rehabilitasi medik yang berbasis pendekatan tim, diharapkan prognosis pasien dengan hemofilia dapat menjadi lebih baik. 
Tabel 3. Penatalaksanaan rehabilitasi medik pada kasus hemofiliaa ${ }^{21}$

\begin{tabular}{|c|c|c|c|}
\hline Komplikasi & Gejala & Tujuan & Jenis penanganan \\
\hline $\begin{array}{l}\text { Perdarahan } \\
\text { sendi akut }\end{array}$ & $\begin{array}{l}\text { - Nyeri pada } \\
\text { palpasi/gerak } \\
\text { - Edema } \\
\text { - Keterbatasan ROM }\end{array}$ & $\begin{array}{l}\text { - Mengurangi nyeri dan } \\
\text { edema } \\
\text { - Mengembalikan } \\
\text { fungsionalitas } \\
\text { - Mencegah perdarahan } \\
\text { lanjut }\end{array}$ & $\begin{array}{l}\text { - RICE, medikamentosa, } \\
\text { TENS, PSWD, US } \\
\text { - Hydrotherapy } \\
\text { - Program latihan LGS } \\
\text { sesuai kondisi pasien } \\
\text { - Edukasi }\end{array}$ \\
\hline $\begin{array}{l}\text { Perdarahan } \\
\text { otot akut }\end{array}$ & $\begin{array}{l}\text { - Nyeri pada } \\
\text { palpasi/gerak } \\
\text { - Keterbatasan ROM } \\
\text { - Muscle imbalance } \\
\text { - Neuropati }\end{array}$ & $\begin{array}{l}\text { - Mengurangi nyeri dan } \\
\text { edema } \\
\text { - Mengembalikan } \\
\text { fungsionalitas } \\
\text { - Mencegah perdarahan } \\
\text { lanjut } \\
\text { - Muscle balance restoring }\end{array}$ & $\begin{array}{l}\text { - RICE, medikamentosa, } \\
\text { TENS, PSWD, US } \\
\text { - Program latihan } \\
\text { bertahap (latihan LGS } \\
\text { dilanjutkan dengan } \\
\text { penguatan otot sesuai } \\
\text { kondisi pasien) } \\
\text { - Edukasi }\end{array}$ \\
\hline $\begin{array}{l}\text { Sinovitis } \\
\text { kronis }\end{array}$ & $\begin{array}{l}\text { - Nyeri (minimal) } \\
\text { - Gangguan } \\
\text { proprioseptif } \\
\text { - Atrofi otot (+/-) }\end{array}$ & $\begin{array}{l}\text { - Mengurangi nyeri dan } \\
\text { edema } \\
\text { - Mengembalikan } \\
\text { fungsionalitas } \\
\text { - Mencegah perdarahan } \\
\text { lanjut } \\
\text { - Meningkatkan kekuatan } \\
\text { dan ketahanan otot } \\
\text { - Memperbaiki fungsi } \\
\text { proprioseptif }\end{array}$ & $\begin{array}{l}\text { - TENS, Medikamentosa, } \\
\text { Hydrotherapy } \\
\text { - Program latihan LGS, } \\
\text { penguatan dan bertahap } \\
\text { - Latihan proprioseptif } \\
\text { - Edukasi }\end{array}$ \\
\hline $\begin{array}{l}\text { Artritis } \\
\text { degeneratif }\end{array}$ & $\begin{array}{l}\text { - Nyeri pada } \\
\text { palpasi/gerak } \\
\text { - Keterbatasan ROM } \\
\text { - Neuropati } \\
\text { - Kelemahan otot } \\
\text { - Kontraktur } \\
\text { - Deformitas (+/-) }\end{array}$ & $\begin{array}{l}\text { - Mengurangi nyeri } \\
\text { - Menjaga fungsionalitas dan } \\
\text { mencegah disabilitas } \\
\text { - Menjaga kekuatan dan } \\
\text { ketahanan otot } \\
\text { - Memperbaiki fungsi } \\
\text { proprioseptif }\end{array}$ & $\begin{array}{l}\text { - TENS, medikamentosa, } \\
\text { hydrotherapy } \\
\text { - Program latihan LGS } \\
\text { penguatan dan } \\
\text { peregangan otot } \\
\text { bertahap } \\
\text { - Latihan proprioseptif } \\
\text { - Brace/splint } \\
\text { - Edukasi }\end{array}$ \\
\hline
\end{tabular}

\section{DAFTAR PUSTAKA}

1. Harper D. Hemofilia [homepage on the Internet]. c2012 [updated 2012 Mar 20; cited 2012 May 28]. Available from: http://www.etymonline.com/index.phps earch=hemofilia\&searchmode=none

2. Murphy P, Wunderlich A, Pico L. Orthopedics and musculoskeletal condition. In: Dennis M, Michael A. Pediatric Rehabilitation: Principles and Practice. New York: Demos Publishing, 2010; p. 377.

3. Hemophiliac's pedigree [Image on the internet]. c2012 [updated 2012 Jan 12; cited 2012 May 28]. Available from: http://medicalera.com/info_answer.php
?Thread $=11638$.

4. Collins PW, Hirsch S, Baglin TP. Acquired hemophilia in the United Kingdom: A 2-year national surveillance study by the United Kingdom Hemophilia Centre Doctor's Organization. Blood. 2007;109:1870-7.

5. Koesoema AM. Penyakit Hemofilia di Indonesia: Masalah Diagnostik dan Pemberian Komponen Darah [Tesis]. Medan: Universitas Sumatra Utara; 2006.

6. Nigel K. Coagulation In: Lillicrap D, Michael M, editors. Practical Homeostasis and Thrombosis. Philadelphia: Wiley-Blackwell, 2009; p. 21-4. 
7. Steven E. Simplified pathways of blood coagulation. In: Polin RA, Ditmar MF, editors. Pediatrics Secrets. Philadelphia: Mosby Elsevier, 2011; p. 307.

8. Powell D, Anderson S, Saduman $O$. Hemophilia overview. [homepage on the Internet]. c2012 [Updated 2009 Nov 24; Cited 2012 May 28]. Available from: http://emedicine.medscape.com/ article/779322-overview.

9. Yeoh G. Hematology. In: Bowman E, Yeoh G, editors. Toronto Notes Pediatrics. New York: Demos, 2010; p. 48.

10. Linderman $\mathbf{C}$, Eichenfield $\mathbf{E}$. The neonate with hemophilia. In: Eichenfield A, Candell E, editors. Textbook of Hemophilia. Singapore: WileyBlackwell, 2010; p. 111.

11. Tarantino MD, Gupta SL. The incidence and outcome of intracranial hemorrhage in newborn with hemophilia. Haemophilia. 2007;13:380-2.

12. WHO. Ageing. [homepage on the Internet]. c2012 [Updated 2012 Feb 16; Cited 2012 May 28]. Available from: http://www.who.int/.

13. Linderman C, Eichenfield E. Care of the child with Hemophilia. In: Liacouras R, editor. Textbook of Hemophilia. Singapore: Wiley-Blackwell, 2010; p. 127.

14. Mark E. Facts for families. In: Samuel E.
The Teen Brain: Behavior, Problem Solving and Decision Making. Washington: Elsevier, 2011; p. 57-58

15. Linderman C, Eichenfield E. Adolescence In: Adamson M, editor. Textbook of Hemophilia. Singapore: WileyBlackwell, 2010; p. 133-5.

16. Summer E. Guidelines for the Management of Hemophilia. Montreal: World Federation of Hemophilia, 2010.

17. Lauren L. Burket's medicine diagnosis. In: Martin S, editor. Bleeding and Clotting Disorders. Philadelphia: B. C. Decker, 2008; p. 458-9.

18. Chandler W, Chris F. Comparison of three methods for measuring factor VIII levels in plasma. Am J Clin Pathol. 2008;120:34-9.

19. Knobe K, Berntrop E. Hemophilia and joint disease: pathophysiology, evaluation and management. Journal of Comorbidity. 2011;1:51-9.

20. Alltree J. Acute muscle bleeds. In: Kareen, B. Alltree J, Cornwall J. Rehabilitation of Muscle Dysfunction. Montreal: World Federation of Hemophilia, 2005; p. 1-4.

21. Linderman C, Eichenfield E. Inhibitors to factor VIII. In: Peerlinck K, Jacobson M, editors. Textbook of Hemophilia. Singapore: Wiley-Blackwell, 2010; p. 62. 